\title{
Prevalence of Equine Wound and Associated Risk Factors in and around Kombolcha Town, North Ethiopia
}

\section{Fikru $A^{1 *}$, Tadese $A^{2}$ and Gebreegziabher $Z^{2}$}

${ }^{1}$ School of Veterinary Medicine, Hawassa University, Ethiopia

${ }^{2}$ Faculty of Veterinary Medicine, University of Gondar, Ethiopia

\begin{abstract}
A cross-sectional study was conducted to determine the prevalence wound and associated risk factors in equines in Kombolcha town, North Ethiopia. A total of 600 working equines were examined of which, $469(78.2 \%)$ and $131(21.8 \%)$ were horses and donkeys, respectively. The overall prevalence of equine wound was $64 \%$ in which $64.2 \%$ and $63.4 \%$ of wound prevalence were detected in horses and donkeys, respectively. The prevalence of wound vary significantly among age categories of both species of animals (Horse: $X^{2}=39.3, P<0.05$ ) and (Donkey: $\left.X^{2}=15.62, P<0.05\right)$ where higher prevalence was noticed in adult horses and donkeys. Slightly higher proportion of wound was encountered in pre scapular areas of the body in both wounded horses (85.4\%) and donkeys (14.6\%). Abrasion, laceration (horses) and punctures (donkey) were among the most frequently encountered types of wounds. The intensity of injuries was highly associated with species $\left(X^{2}=7.2, P<0.05\right)$; injuries were more severe in horses $(38.9 \%)$ than in donkeys $(25.3 \%)$. The majority of these wounds were caused by improper harnesses in both species of animals in which the highest wound prevalence was recorded in horses $(63.9 \%)$ and donkeys $(68.7 \%)$ that used plastic and grass as a harnessing material, respectively. Surprisingly, of positive wound cases, only $33.7 \%$ in donkeys and $12.0 \%$ in horse has got wound treatment; however, the rest were left untreated. Generally, this study has figured out wound as a major health problem of working equines in and around Kombolcha town and hence, a comprehensive equine health programs should be implemented in order to alleviate the prevailing problem.
\end{abstract}

Keywords: Donkeys; Horses; Prevalence; Wound

\section{Introduction}

More than $72 \%$ of the world's horse population is found in developing countries specifically kept for draft purpose [1,2]. Ethiopia has more than 6 million donkeys, the second largest donkey population in the world next to China, 1.9 million horses and over 350,000 mules [3]. Equines are important animals to the resource-poor communities in rural and urban areas of Ethiopia, providing traction power and transport services at low cost [4-6]. In Ethiopia, the rugged terrain characteristics, absence of well-developed modern transport networks and the prevailing low economic status of the community necessitate the use of equines for transportation $[4,6,7]$.

Despite their significant contribution to the communities and the national economy [8], little attention is given to study the health aspects of working equids. The available studies are mainly on the prevalence of infectious diseases [9-15] with limited studies on ocular diseases $[16]$ and external injuries $[17,18]$. Therefore, this study was designed to determine the prevalence and factors associated with the occurrence of wound in equines in kombolcha town, North Ethiopia.

\section{Materials and Methods}

\section{Study area}

The study was conducted in kombolcha town and its surroundings, Northern Ethiopia from October 2011 to April 2012. The area is found $377 \mathrm{~km}$ North East of Addis Ababa with an altitude ranging from 15001840 meters above sea level. The topography is generally marked by the presence of a number of mountains, plateaus, hilly and sloppy areas. The area has a bimodal rainfall with a three year annual average of 1038 $\mathrm{mm}$. The average recorded temperature is $18^{\circ} \mathrm{C}$ and a relative humidity ranging from $23.9 \%$ to $79 \%$ [19].

\section{Study design and sampling}

A cross-sectional study was conducted on randomly selected equines (131 horses and 469 donkeys) from October 2011 to April 2012 in Kombolcha town and its surroundings, North Ethiopia. Since there was no previous study in the area, $50 \%$ expected prevalence was considered to determine the sample size with $95 \%$ confidence level and $5 \%$ absolute precision [20]. Accordingly, the sample size required for the study was 384 but in order to increase precession 600 animals were included.

\section{Study methodology}

Animals subjected to the study were assessed physically for the presence of wounds, the results were recorded according to the sites of wound and representative photographs were taken, when possible. Intensity of wound were classified according to Biffa and Woldemeskel [17] who classified as severe when there was ulceration involving a pronounced contusion in wide areas, tissue hypertrophy and sever complication. Moderate injuries were involving coalition of small wound with tissue sloughing involving no complication and hypertrophy and some with chronic courses. Wounds were categorized as mild when they involve only loss of epidermis and superficial layers with no further trauma. Wounds (injuries) were also classified as abrasion, lacerative, incision and puncture [21]; whereas age of the equines was determined from birth records and the dentition

*Corresponding author: Fikru A, School of Veterinary Medicine, Hawassa University, Ethiopia, Tel: +251-912-082845; E-mail: abrahamfikru@yahoo.com, abrahamf@hu.edu.et

Received February 27, 2015; Accepted May 27, 2015; Published May 29, 2015

Citation: Fikru A, Tadese A, Gebreegziabher Z (2015) Prevalence of Equine Wound and Associated Risk Factors in and around Kombolcha Town, North Ethiopia. J Veterinar Sci Technol 6: 234. doi:10.4172/2157-7579.1000234

Copyright: (C 2015 Fikru A, et al. This is an open-access article distributed unde the terms of the Creative Commons Attribution License, which permits unrestricted use, distribution, and reproduction in any medium, provided the original author and source are credited. 
Citation: Fikru A, Tadese A, Gebreegziabher Z (2015) Prevalence of Equine Wound and Associated Risk Factors in and around Kombolcha Town, North Ethiopia. J Veterinar Sci Technol 6: 234. doi:10.4172/2157-7579.1000234

Page 2 of 4

characteristics [22] and categorized as young ( $<3$ years) and adult $(\geq 3$ years). In addition, semi-structured questionnaire was also used to gather data, such as species, age, injury and management of animals.

\section{Data Analysis}

Data obtained from the study was analyzed using SPSS version 18.0. Chi-square test was used to compare wound prevalence among species and age categories. Whereas, kruskal-wallis test was used to analyze and compare prevalence of wound in relation with harnessing type, intensity, type, position and causes of wound.

\section{Result}

From a total of 600 examined horses and donkeys, 384 (64\%) were having wound in their body parts. Specifically, the variation in prevalence of wound in horses and donkeys was not significant $(\mathrm{P}>0.05)$ (Table 1). The difference in prevalence among age categories was significant $(\mathrm{P}<0.05)$ in both horses and donkeys where the highest prevalence of $69 \%$ and $69.6 \%$ were recorded in adult horses and donkeys, respectively (Table 2).

Significant difference was also observed in the distribution of wounds among different parts of the body parts in both species of animals where the highest numbers of wounds were recorded in pre-scapular areas (Table 3). Furthermore, photographs of wounds in different body parts are illustrated in the Figure 1. There was statistically significant variation among types of wound in both species of the animals $(\mathrm{P}<0.05)$. Abrasion was the highest wound type in both donkeys and horses, however; lacerative and puncture types of wound were the second for horses and donkeys, respectively (Table 4). In addition, the intensity of wound varies significantly $(\mathrm{P}<0.05)$ in both species of animals in which moderate types of wounds were relatively higher in both hoses (43.2\%) and, donkeys (45.8\%), respectively (Table $5)$.

The majority of wounds were caused by improper harness and saddle design, Infectious diseases (only in horses) and by biting (Table 6). The prevalence of wound in relation with their harnessing type (plastic, grass and traditionally prepared leather) is summarized in Table 7. Accordingly, a significant proportion of wound was recorded in horses and donkeys that used plastic and grass as a harnessing material, respectively.

Similarly, there was a significant variation among owners response the on the occurrence of wound in horses and donkeys. Agonizingly, out of 384 wound cases, majority (79.4\%) were left untreated neither by health professional nor by the owners (Table 8 ).

\section{Discussion}

This study has revealed wound as the most prevalent health problem (64\%) of equines in kombolcha town, North Ethiopia. This finding was higher than the $50.2 \%$ prevalence reported in Gondar town, Northern Ethiopia (Demshasha 2011: Faculty of Veterinary Medicine, Addis Ababa University; unpublished data). However, it was slightly lower than the reports of Biffa and Woldemeskel [17] who reported

\begin{tabular}{|c|c|c|c|c|c|}
\hline Species & $\begin{array}{c}\text { No. of examined } \\
\text { animals }\end{array}$ & No of wound & Prevalence & X & P-value \\
\hline Donkey & 131 & 83 & $63.40 \%$ & & \multirow{2}{*}{0.863} \\
\hline Horse & 469 & 301 & $64.20 \%$ & 0.03 & 0.80 \\
\hline Total & 600 & 384 & $64 \%$ & & \\
\hline
\end{tabular}

Table 1: Prevalence of wound between species categories.

\begin{tabular}{|c|c|c|c|c|c|c|}
\hline \multirow{2}{*}{ Species } & $\begin{array}{c}\text { Age } \\
\text { category }\end{array}$ & $\begin{array}{c}\text { Examined } \\
\text { animals (No) }\end{array}$ & $\begin{array}{c}\text { Wounded } \\
\text { animals } \\
\text { (No) }\end{array}$ & Prevalence & $\mathbf{X}^{2}$ & \multirow{2}{*}{ P-value } \\
\hline \multirow{2}{*}{ Horse } & Young & 50 & 12 & $24.00 \%$ & & \multirow{2}{*}{0} \\
\cline { 2 - 6 } & Adult & 419 & 289 & $69.00 \%$ & 39.3 & \multirow{2}{*}{0} \\
\hline \multirow{2}{*}{ Donkey } & Young & 16 & 3 & $18.80 \%$ & & \multirow{2}{*}{ Total } \\
\cline { 2 - 6 } & Adult & 115 & 80 & $69.60 \%$ & 15.6 & \\
\hline \multirow{2}{*}{ Total } & & 600 & 384 & $64 \%$ & & \\
\hline
\end{tabular}

Table 2: Prevalence of wound between age categories.

\begin{tabular}{|c|c|c|c|c|c|}
\hline Position & $\begin{array}{c}\text { No of Horse } \\
(\%)\end{array}$ & $\begin{array}{c}\text { No of Donkey } \\
(\%)\end{array}$ & Total No. (\%) & $x^{2}$ & P-value \\
\hline Head & $2(0.7)$ & $2(2.4)$ & $4(1.0)$ & \multirow{11}{*}{52.124} & \multirow{11}{*}{0} \\
\hline Neck & $19(6.3)$ & $7(8.4)$ & $26(6.8)$ & & \\
\hline Shoulder & $5(1.7)$ & $2(2.4)$ & $7(1.8)$ & & \\
\hline Chest & $26(8.6)$ & - & $26(6.8)$ & & \\
\hline Front limb & $22(7.3)$ & $3(3.6)$ & $25(6.5)$ & & \\
\hline Pre scapular & $152(50.5)$ & $26(31.3)$ & $178(46.4)$ & & \\
\hline Back & $5(1.7)$ & $14(16.9)$ & $19(4.9)$ & & \\
\hline Abdomen & $8(2.7)$ & $6(7.2)$ & $14(3.6)$ & & \\
\hline Hind limb & $26(8.6)$ & 11(13.3) & $37(9.6)$ & & \\
\hline Mixed & $36(12.0)$ & $12(14.5)$ & $48(12.5)$ & & \\
\hline Total & 301 & 83 & 384 & & \\
\hline
\end{tabular}

Table 3: Distribution wound on various body parts.
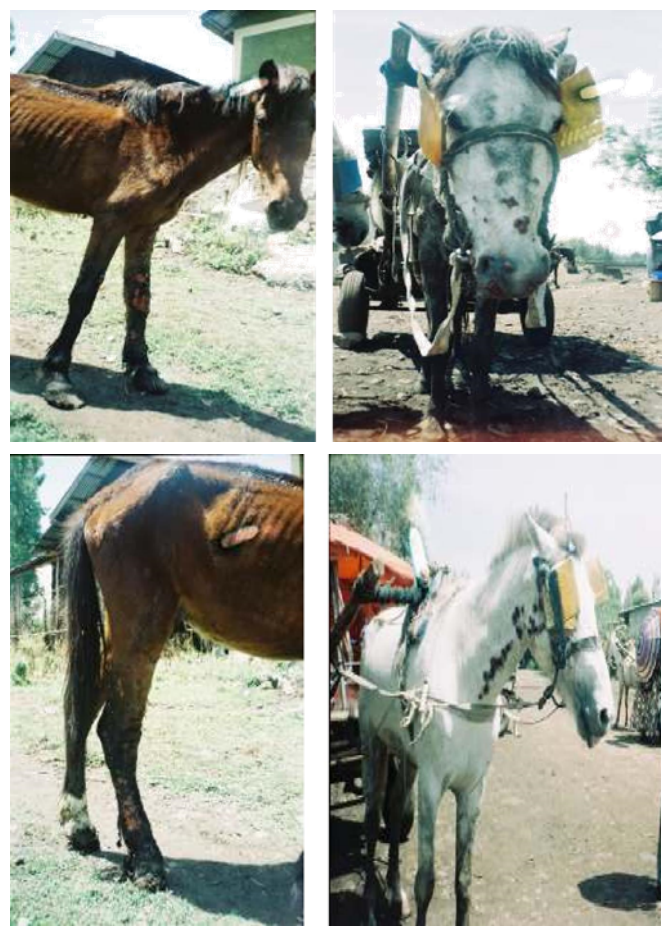

Figure 1: Photographs of wound on different parts of the animal body (captured during the study period).

72.15\% prevalence in Hawassa, Southern Ethiopia. This might be due to variation in management and health care given to equines among these sites. In fact majority of the poor people who obtain their income by providing transport service with the help of equines did not give attention for management, health care and welfare of their animals in the study area. They also overloaded the equines that lead to falling and consequently exposing to injury. 
Citation: Fikru A, Tadese A, Gebreegziabher Z (2015) Prevalence of Equine Wound and Associated Risk Factors in and around Kombolcha Town, North Ethiopia. J Veterinar Sci Technol 6: 234. doi:10.4172/2157-7579.1000234

Page 3 of 4

\begin{tabular}{|c|c|c|c|c|c|}
\hline $\begin{array}{c}\text { Type of } \\
\text { wound }\end{array}$ & No of Horse (\%) & $\begin{array}{c}\text { No of Donkey } \\
\text { (\%) }\end{array}$ & Total No. (\%) & $\mathbf{X}^{2}$ & P-value \\
\hline Abrasion & $195(64.8)$ & $42(50.6)$ & $237(61.7)$ & & \\
\hline Lacerative & $89(29.6)$ & $1(1.2)$ & $90(23.4)$ & & \multirow{2}{*}{1.064} \\
\hline Puncture & $15(5.0)$ & $39(47.0)$ & $54(14.1)$ & \multirow{2}{*}{0} \\
\hline Incision & $2(0.7)$ & $1(1.2)$ & $3(0.8)$ & & \\
\hline Total & 301 & 83 & 384 & & \\
\hline
\end{tabular}

Table 4: Proportion of wound by type.

\begin{tabular}{|c|c|c|c|c|c|}
\hline $\begin{array}{c}\text { Intensity of } \\
\text { wound }\end{array}$ & $\begin{array}{c}\text { No of Horse } \\
(\mathbf{\%})\end{array}$ & $\begin{array}{c}\text { No of Donkey } \\
(\mathbf{\%})\end{array}$ & Total No. (\%) & X' & P-value \\
\hline Sever & $117(38.9)$ & $21(25.3)$ & $138(35.9)$ & \multirow{2}{*}{7.2} & 0.026 \\
\hline Moderate & $130(43.2)$ & $38(45.8)$ & $168(43.8)$ & & \\
\hline Mild & $54(17.9)$ & $24(28.9)$ & $78(20.3)$ & & \\
\hline Total & 301 & 83 & 384 & & \\
\hline
\end{tabular}

Table 5: Intensity of wound among species of animals.

\begin{tabular}{|c|c|c|c|c|c|}
\hline Cause of wound & $\begin{array}{c}\text { No of horse } \\
(\%)\end{array}$ & $\begin{array}{c}\text { No of donkey } \\
(\%)\end{array}$ & $\begin{array}{c}\text { Total No. } \\
(\%)\end{array}$ & $\mathbf{X}^{2}$ & P-value \\
\hline \begin{tabular}{c|c|c|c|} 
Improper harness and \\
saddle
\end{tabular} & $185(61.5)$ & $35(42.2)$ & $220(57.3)$ & & \\
\hline Infectious diseases & $93(30.9)$ & - & $93(24.2)$ & & \\
\hline Biting & $12(4.0)$ & $33(39.8)$ & $45(11.7)$ & & \\
\hline Injury by zebu horn & $1(0.3)$ & $4(4.8)$ & $5(1.3)$ & \multirow{2}{*}{129.69} & \multirow{2}{*}{0} \\
\hline Overload & $2(0.7)$ & $7(8.4)$ & $9(2.3)$ & & \\
\hline Falling & $6(2.0)$ & $2(2.4)$ & $8(2.1)$ & & \\
\hline Unknown & $2(0.7)$ & $2(2.4)$ & $4(1.0)$ & & \\
\hline Total & 301 & 83 & 384 & & \\
\hline
\end{tabular}

Table 6: Causes of wound in horses and donkeys.

\begin{tabular}{|c|c|c|c|c|c|c|}
\hline Species & $\begin{array}{l}\text { Type of } \\
\text { harness }\end{array}$ & $\begin{array}{c}\text { No of } \\
\text { examined }\end{array}$ & $\begin{array}{c}\text { No of } \\
\text { wound }\end{array}$ & Prevalence & $\mathrm{X}^{2}$ & P-value \\
\hline \multirow{2}{*}{ Horse } & Plastic & 465 & 297 & $63.90 \%$ & \multirow[b]{2}{*}{2.252} & \multirow[b]{2}{*}{0.133} \\
\hline & Grass & 4 & 4 & $100 \%$ & & \\
\hline \multirow{3}{*}{ Donkey } & Plastic & 16 & 10 & $62.50 \%$ & \multirow[b]{3}{*}{8.32} & \multirow[b]{3}{*}{0.016} \\
\hline & Grass & 99 & 68 & $68.70 \%$ & & \\
\hline & $\begin{array}{c}\text { Traditionally } \\
\text { prepared } \\
\text { leather }\end{array}$ & 16 & 5 & $31.3 \%$ & & \\
\hline Total & & 600 & 384 & $64 \%$ & & \\
\hline
\end{tabular}

Table 7: Prevalence of wound in relation with harnessing type.

\begin{tabular}{|c|c|c|c|c|c|}
\hline Owners responses & $\begin{array}{c}\text { No of Horse } \\
\text { (\%) }\end{array}$ & $\begin{array}{c}\text { No of Donkey } \\
\text { (\%) }\end{array}$ & $\begin{array}{c}\text { Total No. } \\
(\mathbf{\%})\end{array}$ & X & P-value \\
\hline $\begin{array}{c}\text { Take to nearby } \\
\text { veterinary clinic }\end{array}$ & $36(12.0)$ & $28(33.7)$ & $64(16.7)$ & & \\
\hline Use sulfuric acid & $9(3.0)$ & - & $9(2.3)$ & 23.83 & \multirow{2}{*}{0} \\
\hline Use burned oil & $5(1.7)$ & $1(1.2)$ & $6(1.6)$ & & \\
\hline Do nothing & $251(83.4)$ & $54(65.1)$ & $305(79.4)$ & & \\
\hline Total & 301 & 83 & 384 & & \\
\hline
\end{tabular}

Table 8: Owners' responses to the management of wound.

The prevalence of wounds in donkeys (63.4\% was higher compared with the study reported in peri-urban areas of Ethiopia (44\%) [23] and lower from the findings in Hawassa (79.4\%) [17]. The current finding revealed higher prevalence $(64.2 \%)$ of wound in horses as compared with a study conducted in Mekelle, Northern Ethiopia [18]; however it was comparable with the finding of (65.4\%) Biffa and Woldemeskel [17] in Hawassa, Ethiopia. The variation in prevalence of wound in horses and donkeys at different geographic locations may be due to the variation in husbandry and management.
The present finding has also showed significantly higher prevalence of wound in young animals which is similar with the findings of Biffa and Woldemeskel [17]. This may due to the fact that adult animals exposed to different types of diseases and stress in their entire life which may affect the normal process of wound healing. It could also be attributed by lack regular care, feeding and health care provision to their old equines by most of the owners, as it was clearly observed in the study area.

Significant number abrasion wounds (in both horses and donkeys), lacerative (in horses) and puncture wound (in donkeys) were reported in this study. Damages caused by biting, zebu horn damage and overloading were the causes of wounds in both species of animals which were also reported in Hawassa, Ethiopia [17]. According to Biffa and Woldemeskel [17], after long hours of laborious work, fatigued as well as sick horses and donkeys are often made to find night resting places where they are exposed to hyenas.

Relatively high prevalence of infection-related wounds in horses which were characterized by ulceration, abscess, or suppuration suggests the pathogens as either primary or secondary causes. Mitotic dermatitis, ulcerative and epizootic lymphangitis are the major infectious skin diseases of equines in Ethiopia [24,25] might contribute to the high prevalence of injuries reported in this study.

Improper harness and saddle were among the major causes of injuries in equines which is similar with other reports from peri-urban areas of Ethiopia [17], Gondar, Northern [24] and Mekelle, Northern Ethiopia [18]. Injuries were demonstrated mainly on pre-scapular areas; neck, hind limbs and backside coinciding with poorly designed harnesses and saddles manufactured by unskilled artisans which is commonly practiced in different parts of the country. Equine-drawn carts are often designed unbalanced and too heavy and do not consider load distribution in relation to the body balance and style of movement. Wooden or iron-made saddles are constantly put on the back/shoulder and strongly tied to the body by plastic rope, which causes persistent irritation and injuries. In most cases, harnesses were made of hard plastic strips, which cut in to the skin of the equines and form large open wounds [17].

Majority (79.4\%) of the owners did not provide any treatment to their animals. This indicates the widely existing equine welfare problem in the area similar to the situation reported in Hawassa and peri urban areas of Ethiopia [17,23]. Few owners (16.7\%) treated their sick animals by allowing them to have access to appropriate veterinary care. Even most of those taken to veterinary clinics, were at their terminal stage and no longer able to work. In addition, few owners managed their sick equines by applying sulfuric acid (2.3\%) and burned oil (1.6\%) on wound which may aggravate the wound.

\section{Conclusion and Recommendation}

The present study has revealed high prevalence of wound in working equines in and around Kombolcha town, Ethiopia. Improper harnessing and saddle, and infectious diseases were the major contributor to the higher prevalence of the disease. Even though some of equine owners are used to take their equines to veterinary clinic, majority of them are negligent for the care and handling of their animal, as a result welfare of animals are severely affected. To alleviate the problems, equine health management and welfare promotion program is recommended.

\section{Acknowledgments}

The authors are grateful for the University of Gondar for sponsoring this study. 
Citation: Fikru A, Tadese A, Gebreegziabher Z (2015) Prevalence of Equine Wound and Associated Risk Factors in and around Kombolcha Town, North Ethiopia. J Veterinar Sci Technol 6: 234. doi:10.4172/2157-7579.1000234

\section{References}

1. Fielding D, Pearson RA (1991) Donkeys, Mules and Horses in Tropical Agricultural Development. In: Proceedings of the $1^{\text {st }}$ International Colloquium on Working Equine, 3-6 September 1990. Centre for Tropical Veterinary Medicine, University of Edinburgh, Scotland, 33-47.

2. Swann WJ (2006) Improving the welfare of working equine animals in developing countries. Appl Anim Behav sci 100: 148-151.

3. FAOSTAT (2012) Food and Agricultural Statistical Database: http://www.fao. org/corp/statistics/ access online/.

4. Ameni G (2006) Preliminary trial on the reproducibility of epizootic lymphangitis through experimental infection of two horses. Short Communication. J Veterinary 172: 553-555.

5. Dinka H, Shelima B, Abalti A, Geleta T, Mume T, et al. (2006) Socio-economic importance and management of carthorses in the mid rift valley of Ethiopia. Proceedings of the $5^{\text {th }}$ International Colloquium on Working Equines.

6. Howe J, Garba R (1997) Farm-level transport and animal dependency in Kaffecho Zone, Ethiopia. In: Proceedings of the Animal Transport and Network of Eastern and Southern Africa (ATNESA) Workshop "Improving Donkey Utilization and Management." Debre-zeit Ethiopia.

7. Mengistu A (2003) The genetic resources perspective of equines in Ethiopia and their contribution to the rural livelihoods. Proceedings of the $11^{\text {th }}$ Annual Conference of the Ethiopian Society of Animal Production (ESAP). Addis Ababa, Ethiopia, 81-85

8. Behnke R, Metaferia F (2011) The Contribution of Livestock to the Ethiopian Economy - Part II. IGAD LPI Working Paper No. 02-11. 43.

9. Getachew M, Trawford A, Feseha G, Reid SWJ (2010) Gastrointestinal parasites of working donkeys of Ethiopia. Trop Anim Health Prod 42: 27-33.

10. Hagos A, Abebe G, Buscher P, Goddeeries BM, Claes F (2010) Serological and parasitological survey of dourine in the Arsi-Bale highlands of Ethiopia. Trop Anim Health Prod 42: 769-776.

11. Getachew M, Innocent G, Proudman CJ, Trawford A, Feseha G, et al. (2012) Equine cestodosis: a sero-epidemiological study of Anoplocephala perfoliata infection in Ethiopia. Vet Res Commun 36: 93-98.

12. Gizachew A, Schuster RK, Joseph S, Wernery R, Georgy NS, et al. (2013) Piroplasmosis in Donkeys - A Hematological and Serological Study in Central Ethiopia. J Equine Vet Sci 33: 18-21.
13. Asfaw R, Ameni G, Pal M (2012) Prevalence of Epizootic Lymphangitis in Cart Horses in Southwest Shewa of Oromia Region, Ethiopia. Int J Livest Res 2 : 146-151.

44. Ayelet G, Dersob S, Jemberiea S, Tigre W, Aklilu N, et al. (2013) Outbreak investigation and molecular characterization of African horse sickness virus circulating in selected areas of Ethiopia. Acta Trop 127: 91-96.

15. Getachew M, Alemayehu F, Chala C, Amare, B, Kassa D, et al. (2014) A crosssectional sero-survey of some infectious diseases of working equids in Central Ethiopia. Journal of Veterinary Medicine and Animal Health 6: 231-238.

16. Scantlebury CE, Aklilu N, Reed K, Knottenbelt DC, Gebreab F, et al. (2013) Ocular disease in working horses in Ethiopia: a cross-sectional study. Veterinary Record 1-6.

17. Biffa D, Woldemeskel M (2006) Causes and factors associated with occurrence of external injuries in working equines in Ethiopia. Intern J Appl Res Vet Med: 4: $1-7$.

18. Sisay WZ (2013) Causes and Factors Associated with the Episode of Externa Injuries in Cart-Horses of Mekelle Town, North Ethiopia. J Vet Adv 3: 265-274.

19. Arari (2008) Amhara Regional Agricultural research Institute, Annual report Bahir Dar, Ethiopia.

20. Thrusfield M (2007) Veterinary Epidemiology (3rdedn) Blackwell science Ltd London, UK, 228-246.

21. Feseha GA (1997) In: Elisabeth DS (ed.) Diseases and health problems of donkeys abroad. Professional Hand Book of the Donkeys (3rdedn) White Books Limited, London.

22. Payne WJ (1990) An Introduction to Animal Husbandry in the Tropics (4thedn) Long Man Scientific and Technical: United Kingdom.

23. Pearson RA, Mengistu A, Agajie T, Eleanor FA, David GS, et al. (2000) Use and management of donkeys in peri-urban areas of Ethiopia. Centre for Tropical Veterinary Medicine: University of Edinburgh, Scotland. Draught Animal Power Technical Report 5.

24. Helen B (2001) The Gharry horses of Gonder. Draught Animal News. Centre for Tropical Veterinary Medicine: University of Edinburgh, Scotland, 35: 23-24.

25. Gobena A (2001) Epizootic lymphangitis: study on its epidemiology and socioeconomic importance in carthorses in selected sites of Ethiopia. In Proceedings of the $15^{\text {th }}$ Annual Conference of Ethiopian Veterinary Association. Addis Ababa, Ethiopia. 